\title{
THE HEDONIC PRICE STRUCTURE OF FACULTY COMPENSATION AT U.S. COLLEGES AND UNIVERSITIES
}

\author{
David E. Clark and Thomas A. Knapp ${ }^{*}$
}

\begin{abstract}
Economic theory suggests that the variation in academic salaries across institutions in part reflects compensating differences associated with variation in the levels of local "quality of life" factors such as environmental quality and the provision of local public services. This paper presents an econometric analysis of the hedonic, or implicit price structure, of faculty compensation at U.S. colleges and universities using data from AAUP merged with data on a host of location-specific characteristics. Quality of life factors are found to be important, accounting for between 7 percent and 12.8 percent of total compensation.
\end{abstract}

\section{INTRODUCTION}

Each April, the journal Academe publishes the American Association of University Professors' (AAUP) comprehensive survey of average salaries and benefits, by academic rank, paid to faculty at colleges and universities in the United States, for various categories of institutions. This survey is no doubt scrutinized by faculty members who wish to compare their compensation to that of individuals within and across institutions, while administrators likely view the survey in terms of how their own institutions' salaries compare to peer institutions with which they compete for faculty. In trying to interpret these data, one should consider productivity differences associated with the faculty of the institutions, as well as compensating differences which are related to the characteristics of the institutions' location. The existence of both types of factors relies upon the assumption that equilibrium prevails in the academic labor market. Let us first consider productivity differences.

In long-run equilibrium under perfectly competitive market conditions, faculty in a given discipline would be efficiently distributed across institutions so that remaining variations in compensation would reflect variation in productivity. ${ }^{1}$ There are possible impediments to the attainment of such an equilibrium. For ex-

\footnotetext{
*Associate Professor of Economics, Marquette University, and Associate Professor of Economics, Pennsylvania State University-Wilkes Barre Campus. The authors would like to thank Michael Greenwood and Gary Hunt for their insights on an earlier draft of the paper that was presented at the Western Regional Science Association Annual Meetings in Tucson, Arizona, February 23-27, 1994. We also thank AAUP, and especially Daniel Hamermesh, for providing us with the faculty compensation data. Finally, Yingqiu Liu and Craig Foreman provided invaluable assistance in the collection and assembly of data.
} 
ample, one would expect certain salary differentials to remain after fully accounting for productivity factors, reflecting moving costs or other transaction costs. In addition, institutional forces such as the tenure system create barriers to mobility, and imperfect information about alternative jobs may also prevent the achievement of equilibrium. However, there is a second factor which explains wage or salary differentials between institutions, and it is related to differences in the characteristics of the job location. A large body of research on regional wage differentials and the quality of life across urban areas suggests that the variation in earnings across locations in part reflects compensating differences, associated with variation in the levels of location-specific goods such as environmental quality and the provision of local public services. These goods are purchased only through access to specific locations. For example, access to a more pleasant climate is consumed via migration to the appropriate region. Through the location choices of households, a given desirable attribute becomes indirectly priced through a mix of lower wages, higher local prices, and higher housing costs. In long-run equilibrium, the distribution of households is such that satisfaction is everywhere equalized. The resulting variation in wages, rents, and other local prices reflects the implicit value placed upon locational attributes. This information can be utilized to estimate society's willingness to pay for improvements in these location attributes. Furthermore, the analysis can also be used to investigate the nature of geographic variations in salaries for given occupations. Thus, in the case of academic salaries, the raw data do not accurately reflect the true variation in compensation across institutions, since adjustments for the hedonic component embedded in salary or total compensation structures have not been fully developed. Just as the human capital model explains wage differentials by examining productivity differences in an equilibrium setting, hedonic models also assume equilibrium. That is, wage differentials are just those that are necessary to maintain equal satisfaction across space. If the market is in regional disequilibrium, the accuracy of hedonic analysis is called into question.

Clearly, one would prefer to control for individual differences in productivity in an endeavor to explain faculty salaries across locations. Indeed, for the academic labor market, a number of studies utilize microdata, typically gathered from a small sample of universities. Such research has studied the relationship between personal and productivity characteristics and earnings, focusing upon issues such as the impact of gender, rate of publications, or choice of field of specialization upon earnings. See, for example, Katz (1973), McDowell (1982), Barbezat (1987) and Kenny and Studley (1993). However, this genre of research has not addressed the issue of compensating variations associated with quality of life differences across locations. Because of the geographic incompleteness of the sampling used in these studies, such research is incapable of addressing the issue of 
compensating differences. Indeed, by failing to control for the impact of quality of life factors upon earnings, studies which happen to use sample data from multiple schools may be misspecified, while those focusing on a single school are, in effect, holding location-specific factors constant.

To date, relatively little research has explored the hedonic component of faculty compensation. Exceptions include Bayless (1982), who utilized AAUP data from the early 1970's to explore the willingness to pay for air quality. More recently, Jones and Ressler (1993) consider South versus Nonsouth salary differentials using state-level data.

This study develops an econometric analysis of the hedonic, or implicit, price structure of faculty compensation (salaries plus fringe benefits) for 175 Ph.D.granting U.S. colleges and universities for 1989-1990. The compensation data is merged with measures of institutional quality and a host of county-and/or MSAlevel measures. These site characteristics are categorized as amenities, size/metro characteristics, fiscal measures, and disequilibrium measures. We develop and estimate a wage opportunity locus, where the partial derivative of the wage opportunity locus with respect to, for example, a given amenity, represents the implicit price of that amenity. We derive the implicit prices for various site characteristics and develop a quality of life index. The quality of life indices are dissaggregated so that the relative contributions of the various categories of location-specific factors can be seen. The results suggest that the national structure of faculty compensation is in part reflective of hedonic compensation for a number of quality of life factors. The paper is arranged as follows. Section II reviews the relevant literature. Section III describes the theoretical model, while Section IV presents the empirical model. The final section presents the empirical findings and concludes the paper.

\section{THE LITERATURE}

A number of major research efforts over the last decade have established the importance of compensating differences in explaining variation in wages across locations. Examples of such work include Rosen (1979), Roback (1982), Blomquist, Berger and Hoehn (1988), Berger, Blomquist and Waldner (1987), Hoehn, Berger and Blomquist (1987), and Gyourko and Tracy (1989). These studies have compared the quality of life available in alternative U.S. urban areas, as reflected in variations in earnings and housing prices. However, few studies have explicitly investigated the hedonic structure in a specific job category. This is a contribution of the present study. 
The only study which has examined compensating differences for the national academic market is the one made by Bayless (1982), which utilized a sample of 126 U.S. Ph.D.-granting universities. Bayless explored the impact of air quality upon the salaries of faculty by rank for a period in the early 1970s. The present study improves upon the Bayless study in a number of respects. We extend the data set to include $175 \mathrm{Ph}$.D.-granting institutions, using a more recent time period, 1989-1990. Bayless used a limited number of variables to represent locational characteristics. He focused upon air quality and climate, and he used factor analysis to control for a number of other regressors. In addition, Bayless did not control for property values in his study. Following Roback (1982), it is essential that hedonic wage studies control for housing values, since amenity values tend to be embedded in both wages and rents. ${ }^{2}$ Also, unlike the Bayless study, we control for two distinct and important categories of location specific amenities. The work of Blomquist, Berger and Hoehn (1988), and Gyourko and Tracy (1989), have demonstrated that one must expand the amenity coverage beyond "natural" amenities such as climate, to more complete measures of local quality of life. For example, Ofek, Kahn and Clark (1991), Whaples (1991) and Herzog and Schlottmann (1993) find that population size and scale economies play an important role in the assessment of quality of life across urban areas. ${ }^{3}$ We therefore control for factors related to metropolitan status and population density in our empirical work. In addition, Gyourko and Tracy (1989), show that local fiscal variables (i.e., both taxes and expenditure levels) have a significant influence on local wages. We control for fiscal conditions by using variables reflecting local tax burdens and measures of local public services.

\section{THE THEORETICAL MODEL}

An extensive literature exists on the theory of compensating differences. The model developed here follows the work of Henderson (1982). In equilibrium, consumer mobility guarantees that the same indirect level of utility $\mathrm{V}^{*}$ is achieved at all locations, given variations in the price of housing $\mathrm{P}_{\mathrm{h}}$, wages $\mathrm{W}$, and the amenity vector A. All other goods are uniformly available and are thus compressed into a composite good whose price is unity. Equation (1) below describes these factors.

$$
\mathrm{V}^{*}=\mathrm{V}\left(\mathrm{P}_{\mathrm{h}}, \mathrm{W}, 1 ; \mathrm{A}\right)
$$


We employ the implicit function theorem to solve for wages in terms of housing prices, amenity levels, and the exogenous utility level, $\mathrm{V}^{*}$, leaving us with equation (2) below:

$$
\mathrm{W}_{\mathrm{a}}=\mathrm{W}_{\mathrm{a}}\left(\mathrm{V}^{*}, \mathrm{P}_{\mathrm{h}}, 1 ; \mathrm{A}\right)
$$

Equation (2) describes an indifference surface in wage and amenity space. What is empirically observable is a wage-amenity tradeoff, which reflects the interaction between household wage acceptances and firm wage offers. The wage offer functions of various firms depict the impact of the given amenity upon productivity (shown as $F_{01}$ through $F_{03}$ in Figure 1). The wage acceptance loci, $W_{a 1}$ through $\mathrm{W}_{\mathrm{a} 3}$ in Figure 1, depict individuals with different amenity preferences. The reconciliation of these forces generates a reduced-form equation (3) which Henderson (1982) defines as a wage opportunity locus, $W_{0}$.

$$
\mathrm{W}_{\mathrm{o}}=\mathrm{W}_{0}\left(\mathrm{P}_{\mathrm{h}}, 1 ; \mathrm{A}\right)
$$

The wage opportunity locus is an envelope, reflecting the equilibrium tradeoff between the given amenity and wages. The slope of the wage opportunity locus is defined as an implicit price. Although the wage acceptance function differs from the wage opportunity locus, there are conditions under which the implicit price derived from $W_{0}$ is equivalent to the willingness to pay (i.e., slope of $W_{a}$ ). Willingness to pay and the implicit prices are the same if one can assume that the amenity tradeoff is continuous, ${ }^{4}$ and that the labor market is in long-run equilibrium. Recently, the issue of labor market equilibrium has received considerable attention. Greenwood, Hunt, Rickman and Treyz (1991), and Herzog and Schlottmann (1993) have explored the impact of disequilibrium upon amenity valuations. Both studies conclude that the assumption of equilibrium in labor markets is unjustified, and that more accurate estimates of willingness to pay can be found by determining the wage premium which is required to prevent out-migration. Another issue is raised by Kahn (1987), who finds that the preferences of marginal (or more generally, recent entrants) into a given sector of the labor market tend to dominate the implicit market for occupational safety. The preferences of workers with more job tenure tend to be discounted in part due to their comparatively lower degree of mobility. Both the issues of equilibrium and mobility, as they relate to the current empirical application, will be discussed in the next section of the paper. 


\section{FIGURE 1}

Household Wage Acceptance Functions,

Firm Wage Offer Functions, and Wage Opportunity Locus

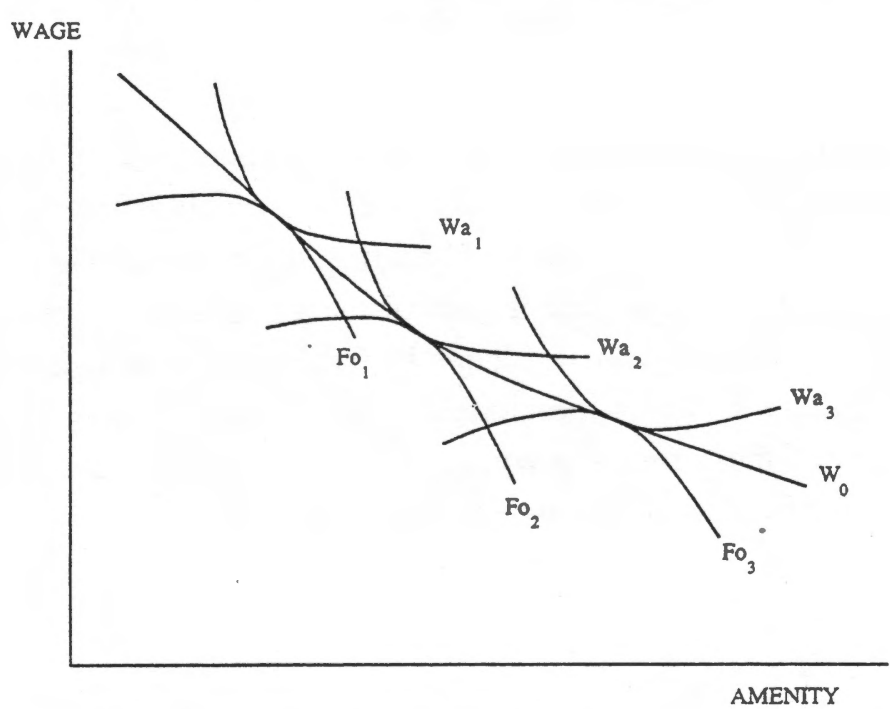

Once implicit price estimates $\left(\tau_{i}\right)$ for a wide range of location-specific characteristics $\left(\mathrm{X}_{\mathrm{i}}\right)$ are derived, a quality of life index is computed as the weighted sum of the amenity level, where the weights are computed implicit prices (i.e., $\left.\mathrm{QOLI}=\Sigma \tau_{\mathbf{i}}{ }^{*} \mathrm{X}_{\mathbf{i}}\right)$. The term quality of life is actually a misnomer, since by assumption, utility levels are everywhere equal. The QOLI reflects the monetized value of the site-specific goods found at that location, and thus the value of the QOLI can be interpreted as the wage cuts which residents are willing to accept to live in that location. Indeed, it is these wage differentials which serve to maintain constant spatial utility levels.

\section{EMPIRICAL MODEL}

\section{Data}

The source of the faculty compensation data is the American Association of University Professors' (AAUP) comprehensive survey of average salaries and fringes, by academic rank and gender, paid to faculty at Colleges and Universities in the U.S., by category of institution. AAUP made available to us data on faculty compensation by institution and rank for 1989-1990, although the gender breakdown was not provided. Since the AAUP data is not a microdata set, it does not 
permit control for individual characteristics which may influence productivity. Furthermore, it does not allow us to control for academic discipline, or individual factors (other than rank) which may proxy amenity preferences. Thus, the estimates will undoubtedly suffer from aggregation bias. However, the AAUP data is the only geographically complete data set available for the study of faculty compensation, and insofar as compensation levels are set institutionwide, implicit valuations can be derived from aggregate data. In addition, since the data is defined by academic rank, control for the sex composition by rank is possible, and to the extent that mobility is correlated with faculty rank, it provides at least partial control for mobility. Furthermore, by including university-provided resources in the specification, we can at least partially account for productivity differences.

The compensation data for each faculty rank (TOTCOMP $\mathrm{Pank}^{5}$ is matched with a vector of variables about the specific institution and its faculty (INSTITUTION), as well as a wide range of location-specific data contained in the vectors AMENITY, SIZE, FISCAL, and DISEQUILIBRIUM. So, to be consistent with the specification in Henderson (1982), the variable median home value (MEDVALUE) is also included in the list of independent variables. Complete variable definitions and data sources are found in Table 1, and descriptive statistics are presented in Table 2.

\section{Model Specification}

Consistent with human capital theory, we employ a semilog functional form, and the separate wage opportunity loci are defined by equation (4).

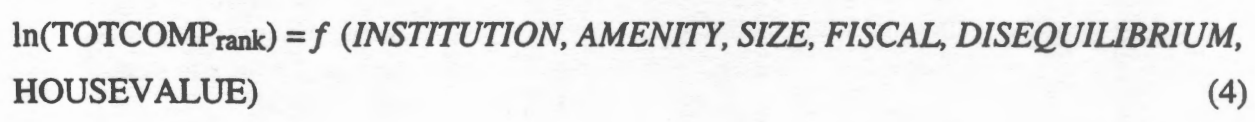

Among the variables contained in the vector INSTITUTION are dummy variables for private universities. To account for the possibility that compensation structures differ between public, private religious, and private nonreligious universities, two dummy variables are included (PRIVATERELIG, PRIVATENONRELIG). The percent of the faculty that is at the associate or full professor level (PCTSENIOR) is included to account for the influence of faculty mix on the overall structure of compensation. For example, universities with a significant proportion of senior faculty may successfully increase fringes, ceteris paribus. In addition, the inclusion of this variable also provides some control for firm-specific human capital. The compensation data is not sex-specific, and thus we include the percent of the faculty (by academic rank) that are male to account 
TABLE 1

Variable Names, Definitions, and Data Sources

\begin{tabular}{|c|c|}
\hline Variable Name & Description \\
\hline TOTCOMP & $\begin{array}{l}\text { Total compensation per year (earnings } \\
\text { plus benefits, by rank, in dollars). }\end{array}$ \\
\hline MEDVALUE & $\begin{array}{l}\text { Median value of single family homes } \\
\text { in the county in } 1990 \text {. }\end{array}$ \\
\hline PRIVATENONRELIG & $\begin{array}{l}1=\text { Private nonreligious university } \\
0=\text { Otherwise }\end{array}$ \\
\hline PRIVATERELIG & $\begin{array}{l}1=\text { Private religiously affiliated univer- } \\
\text { sity } \\
0=\text { Otherwise }\end{array}$ \\
\hline
\end{tabular}

PCTSENIOR

Percent of faculty who hold the rank of associate or full professor (includes instructors).

PCTMALE

Percent of the particular rank that is male.

1990 American Association of University Professors

Academe, Special Issue (March-April, 1991). The Annual Report on Economic Status of the Profession, 19901991.

UNION

$1=$ University faculty are covered by a union contract.

$0=$ Otherwise

1991 Directory of Faculty Contracts and Bargaining Agents in Institutions of Higher Education.

LIBVOLUMES Number of volumes in the library.

R\&DPERFAC

Research and development expenditures (in dollars) per faculty member (not including instructors).

SUNSHINE

Percent of available sunshine in the SMSA or the closest SMSA, based on 30 -year average.

HUMIDITY Average afternoon July humidity level in the SMSA or the closest SMSA, based on 30-year average.

OZONENA

$1=$ County is in nonattainment of ozone air quality standards for 1988 $0=$ County is in attainment.

HGWYDENS 1988 Total county road mileage density (miles of road per square mile).

American Library Dictionary, 1992-1993.

National Science Foundation/SRS, Survey of Scientific and Engineering Expenditures at Universities and Colleges, 1992.

1983 County and City Data Book.

U.S. National Oceanic and Atmospheric Administration, Comparative Climatic Data, 1984.

Environmental Protection Agency

Federal Highway Administration, 1988 Special Report on County Road Mileage. 
TABLE 1 (Continued)

Variable Names, Definitions, and Data Sources

\begin{tabular}{|c|c|c|}
\hline Variable Name & Description & Source \\
\hline POPDENSITY & $\begin{array}{l}1988 \text { County population in thousands } \\
\text { divided by square miles of county } \\
\text { land area. }\end{array}$ & $\begin{array}{l}1990 \text { National Planners As- } \\
\text { sociation, and } 1983 \text { County } \\
\text { and City Databook. }\end{array}$ \\
\hline CNTRLCITY & $\begin{array}{l}1=\text { Central city county of a } \\
\text { metropolitan area. } \\
0=\text { Otherwise. }\end{array}$ & $\begin{array}{l}1988 \text { County and City } \\
\text { Databook. }\end{array}$ \\
\hline SUBURBAN & $\begin{array}{l}1=\text { suburban county of a metropolitan } \\
\text { area. } \\
0=\text { Otherwise. } \\
\text { based on } 1983 \text { MSA definition. }\end{array}$ & \\
\hline EFFPROPTX & $\begin{array}{l}1987 \text { Average statewide effective } \\
\text { property tax rate, existing single fami- } \\
\text { ly homes with FHA-insured } \\
\text { mortgages. }\end{array}$ & $\begin{array}{l}1990 \text { Significant Features of } \\
\text { Fiscal Federalism: Volume 1, } \\
\text { Budget Processes and Tax Sys- } \\
\text { tems. }\end{array}$ \\
\hline INCOMETAX & $\begin{array}{l}1989 \text { State marginal individual in- } \\
\text { come tax rates for single individuals } \\
\text { or married filing jointly. Marginal tax } \\
\text { rate defined according to reported } \\
\text { average salary in AAUP data. }\end{array}$ & $\begin{array}{l}1990 \text { Significant Features of } \\
\text { Fiscal Federalism: Volume 1, } \\
\text { Budget Processes and Tax Sys- } \\
\text { tems. }\end{array}$ \\
\hline PCEDUCATN & $\begin{array}{l}1987 \text { Countywide expenditure on } \\
\text { education per capita. }\end{array}$ & $\begin{array}{l}1993 \text { County and City Extra: } \\
\text { Annual Metropolitan, City } \\
\text { and County Databook. }\end{array}$ \\
\hline PCPOLICE & $\begin{array}{l}1987 \text { Countywide expenditure on } \\
\text { police per capita. }\end{array}$ & $\begin{array}{l}1993 \text { County and City Extra: } \\
\text { Annual Metropolitan, City } \\
\text { and County Databook. }\end{array}$ \\
\hline PCWELFARE & $\begin{array}{l}1987 \text { Countywide expenditure on wel- } \\
\text { fare per capita. }\end{array}$ & $\begin{array}{l}1993 \text { County and City Extra: } \\
\text { Annual Metropolitan, City } \\
\text { and County Databook. }\end{array}$ \\
\hline MIGRRATE & $\begin{array}{l}\text { Change in county population between } \\
1980 \text { and } 1986 \text { divided by thousands }\end{array}$ & $\begin{array}{l}1988 \text { County and City } \\
\text { Databook }\end{array}$ \\
\hline
\end{tabular}

SOUTH 1=University located in South Atlantic, East South Central, or West South Central Census Division.

$0=$ Otherwise.

MIDWEST 1=University located in East North

Central or West North Central Census

Division.

$0=$ Otherwise.

WEST $\quad 1=$ University located in Mountain or Pacific Census Division.

$0=$ Otherwise. 
TABLE 2

Descriptive Statistics ${ }^{a}$

\begin{tabular}{|c|c|c|c|c|}
\hline Variable & Mean & Std Dev & Minimum & Maximum \\
\hline \multicolumn{5}{|l|}{ Dependent Variables } \\
\hline $\begin{array}{l}\text { TOTCOMPFULL } \\
\text { TOTCOMPASSOC. } \\
\text { TOTCOMPASSIST. }\end{array}$ & $\begin{array}{l}70912.57 \\
52853.14 \\
44310.86\end{array}$ & $\begin{array}{r}11124.50 \\
6509.74 \\
4819.12\end{array}$ & $\begin{array}{l}42100.00 \\
35900.00 \\
31500.00\end{array}$ & $\begin{array}{r}100400.00 \\
74900.00 \\
58900.00\end{array}$ \\
\hline \multicolumn{5}{|l|}{ Independent Variables } \\
\hline MEDVALUE & 107500.60 & 79911.28 & 12600.00 & 487300.00 \\
\hline \multicolumn{5}{|c|}{ Institutional Measures } \\
\hline PRIVATENONRELIG & 0.25 & 0.44 & 0.00 & 1.00 \\
\hline PRIVATERELIG & 0.07 & 0.26 & 0.00 & 1.00 \\
\hline PCTSENIOR & 72.92 & 5.31 & 57.24 & 90.63 \\
\hline PCTMALEFULL & 89.93 & 5.44 & 46.07 & 99.29 \\
\hline PCTMALEASSOC. & 75.87 & 7.05 & 38.89 & 92.41 \\
\hline PCTMALEASSIST. & 63.26 & 9.53 & 18.52 & 95.45 \\
\hline UNION & 0.11 & 0.32 & 0.00 & 1.00 \\
\hline LIBVOLUMES & $1.89 \mathrm{E}+6$ & $1.70 \mathrm{E}+6$ & 10000.00 & $1.19 \mathrm{E}+7$ \\
\hline R\&DPERFAC & 130.50 & 133.37 & 10.44 & 1171.48 \\
\hline \multicolumn{5}{|c|}{ Amenity Measures } \\
\hline SUNSHINE & 60.54 & 7.68 & 45.00 & 89.00 \\
\hline HUMIDITY & 52.81 & 11.07 & 19.00 & 83.00 \\
\hline OZONENA & 0.55 & 0.50 & 0.00 & 1.00 \\
\hline HGWYDENS & 5.87 & 6.49 & 0.29 & 40.71 \\
\hline PCVIOLENT & 5.89 & 4.67 & 0.14 & 26.04 \\
\hline \multicolumn{5}{|c|}{ Size and Metropolitan Measures } \\
\hline POPDENSITY & 2.29 & 4.53 & $2.2 \mathrm{E}-3$ & 23.99 \\
\hline CNTRLCITY & 0.78 & 0.42 & 0.00 & 1.00 \\
\hline SUBURBAN & 0.07 & 0.25 & 0.00 & 1.00 \\
\hline \multicolumn{5}{|c|}{ Fiscal Measures } \\
\hline PCEDUCATN & 981.03 & 2070.35 & 20.81 & 23451.48 \\
\hline PCPOLICE & 152.20 & 312.81 & 2.41 & 2763.92 \\
\hline PCWELFARE & 153.93 & 389.29 & 0.00 & 2381.91 \\
\hline EFFPROPTX & 1.26 & 0.49 & 0.22 & 2.38 \\
\hline INCOMETXFULL & 5.50 & 2.75 & 0.00 & 10.00 \\
\hline INCOMETX & 5.34 & 2.80 & 0.00 & 10.00 \\
\hline INCOMETX & 5.33 & 2.78 & 0.00 & 9.50 \\
\hline \multicolumn{5}{|c|}{ Location Dummy Variables and Disequilibrium Controls } \\
\hline MIDWEST & 0.25 & 0.43 & 0.00 & 1.00 \\
\hline SOUTH & 0.33 & 0.47 & 0.00 & 1.00 \\
\hline WEST & 0.20 & 0.40 & 0.00 & 1.00 \\
\hline MIGRRATE & 10.36 & 70.41 & -109.49 & 311.42 \\
\hline
\end{tabular}

${ }^{\mathrm{a}}$ Based on 175 observations. 
for sex-related differences in compensation. Furthermore, the dummy variable UNION is incorporated to account for the effects of organized labor contracts on the total compensation of faculty. Finally, the number of library volumes and the research and development expenditures per faculty are included to control for university-provided resources available to faculty.

The vector AMENITY contains several variables which are meant to capture climatic and other amenity measures in the locality. Unfortunately, data on climate is not reported for nonmetropolitan counties. Thus, we proxy nonmetropolitan climate data by that of the closest metropolitan area if the county in which the university resides is nonmetropolitan. ${ }^{6}$ Two climate variables are included: the percent of the available sunshine (SUNSHINE) and the average afternoon humidity reading in July. Air quality is proxied by the existence of ozone nonattainment (OZONENA) in the county in which the university resides. Highway density (HGWYDENS) proxies several different influences which may be conflicting. For example, high density levels may reflect traffic congestion or measure enhanced accessibility of a particular county to employment within the county or in other counties. Finally, the violent crime rate (PCVIOLENT) is used to measure the public safety amenity.

The vector SIZE captures the influence of population, as well as the metropolitan nature of the region. The variables included under this heading include the population density of the county in which the university resides (POPDENSITY), and whether the county is a central city (CNTRLCITY) or a suburban (SUBURBAN) county within a metropolitan area. Collectively, these variables may capture several distinct influences. For example, densely populated or metropolitan counties may offer a variety of cultural and recreational amenities which are not available in less densely populated or rural counties. Alternatively, more rural settings may offer more opportunities for certain forms of outdoor recreation.

To capture the effects of local public goods and their tax prices on faculty compensation, two tax rates and three types of local expenditures are included in the vector, FISCAL. Tax rates for property (EFFPROPTX), and income (INCOMETX) are included separately. All tax variables are defined at the statewide level, ${ }^{7}$ with the latter variable defined as that rate that is marginal to the respective faculty rank at the university. Per capita expenditures on education (PCEDUCATN), police (PCPOLICE) and welfare (PCWELFARE) are included to approximate local service levels. Note that these measures may or may not be treated as goods by faculty. As an example, high levels of welfare may be viewed as undesirable income redistribution.

Following Henderson (1982), we incorporate several other variables. First, the median housing value is included to approximate average housing value in the 
county. This variable is necessary if coefficients of the wage opportunity loci are to fully reflect the implicit price for the local characteristic. Second, regional dummy variables for the four broad census divisions and the overall migration rate (MIGRRATE) ${ }^{8}$ into the county are included to partially control for regional disequilibrium (DISEQUILIBRIUM). Henderson suggests that wage differentials that remain after controlling for amenities are an indication of regional disequilibrium. However, this interpretation is true only if all other influences are controlled. It is possible, and indeed likely, that these measures are also capturing amenity and disamenity influences related to unmeasured climate variables, as well as counties that have grown quickly since 1980 . Since our primary concern is in having adequate control for the various spatial influences, we deem it important to include the variables, but we caution the reader that the precise interpretation of individual coefficients in this category are unknown.

\section{v. EMPIRICAL FINDINGS AND DISCUSSION}

\section{Regression Results}

Equation (4) is estimated using ordinary least squares ${ }^{9}$ and the White test for heteroskedasticity reveals that the uncorrected error terms are homoskedastic. Ordinary least squares regressions for full, associate and assistant professors are reported in Table 3. A Chow test reveals that pooling of faculty across rank is inappropriate. However, even though the parameter estimates differ significantly between faculty, the findings are remarkably similar across the three equations. The models explain between 50 and 67 percent of the variation in total compensation, with the explained variation rising with faculty rank. The variable MEDVALUE is positive and significant for all ranks of faculty, indicating that faculty require higher wages if they are forced to work in areas where the living expenses are high. In the INSTITUTION category, several variables are statistically significant. Private universities generally pay higher compensation levels than do public schools, although the differences are only significant for senior faculty. The presence of a high percentage of senior faculty raises total compensation for all three compensation equations, as does the percent of the faculty that are male. While the positive and significant coefficients on PCTMALE in all three regression models may be indicative of sex discrimination for faculty, we suggest that such an interpretation, based solely on these findings, is unwarranted. This is because female faculty are not evenly distributed across disciplines, and hence the coefficient may also reflect the relative distribution of male versus female faculty in high paying disciplines. The existence of a union contract covering faculty has 


\section{TABLE 3}

Regression Findings: Wage Opportunity Locus

Dependent Variable $=$ Log of Total Compensation by Rank (t-statistics in parentheses)

\begin{tabular}{|c|c|c|c|}
\hline & \multicolumn{3}{|c|}{ Faculty Rank } \\
\hline INTERCEPT & $\frac{\text { Full }}{10.08117}$ & Associate & $\frac{\text { Assistant }}{10.19486}$ \\
\hline & $\begin{array}{c}10.08117 \\
(48.18)\end{array}$ & $\begin{array}{c}10.35084 \\
(64.71)\end{array}$ & $(70.76)$ \\
\hline MEDVALUE & $\begin{array}{c}9.02 \mathrm{E}-07 \\
(3.72)\end{array}$ & $\begin{array}{c}\text { 5.97E-07 } \\
(2.72)\end{array}$ & $\begin{array}{c}4.07 \mathrm{E}-07 \\
(1.99)\end{array}$ \\
\hline \multicolumn{4}{|c|}{ Institutional Measures } \\
\hline PRIVATENONRELIG & $\begin{array}{c}0.051296 \\
(2.22)\end{array}$ & $\begin{array}{c}0.031342 \\
(1.52)\end{array}$ & $\begin{array}{c}0.005918 \\
(0.29)\end{array}$ \\
\hline PRIVATERELIGOUS & $\begin{array}{c}0.078603 \\
(2.57)\end{array}$ & $\begin{array}{c}0.054768 \\
(2.00)\end{array}$ & $\begin{array}{c}0.035645 \\
(1.37)\end{array}$ \\
\hline PCTSENIOR & $\begin{array}{c}0.004135 \\
(2.70)\end{array}$ & $\begin{array}{c}0.003426 \\
(2.46)\end{array}$ & $\begin{array}{c}0.004605 \\
(3.54)\end{array}$ \\
\hline PCTMALE & $\begin{array}{c}0.007468 \\
(4.99)\end{array}$ & $\begin{array}{l}0.00387 \\
(3.77)\end{array}$ & $\begin{array}{c}0.002811 \\
(3.94)\end{array}$ \\
\hline UNION & $\begin{array}{c}-0.01293 \\
(-0.49)\end{array}$ & $\begin{array}{c}-8.3 \mathrm{E}-05 \\
(-0.00)\end{array}$ & $\begin{array}{c}-0.00557 \\
(-0.25)\end{array}$ \\
\hline LIBVOLUMES & $\begin{array}{c}2.53 \mathrm{E}-08 \\
(5.32)\end{array}$ & $\begin{array}{c}\text { 9.73E-09 } \\
(2.28)\end{array}$ & $\begin{array}{c}9.87 \mathrm{E}-09 \\
(2.44)\end{array}$ \\
\hline R\&DPERFAC & $\begin{array}{c}\text { 7.65E-05 } \\
(1.34)\end{array}$ & $\begin{array}{c}5.44 \mathrm{E}-05 \\
(1.06)\end{array}$ & $\begin{array}{c}1.95 \mathrm{E}-05 \\
(0.40)\end{array}$ \\
\hline \multicolumn{4}{|c|}{ Amenities } \\
\hline SUNSHINE & $\begin{array}{c}-0.00268 \\
(-1.88)\end{array}$ & $\begin{array}{c}-0.00336 \\
(-2.59)\end{array}$ & $\begin{array}{c}-0.00249 \\
(-2.04)\end{array}$ \\
\hline HUMIDITY & $\begin{array}{c}0.000282 \\
(0.26)\end{array}$ & $\begin{array}{c}0.000188 \\
(0.19)\end{array}$ & $\begin{array}{c}0.000122 \\
(0.13)\end{array}$ \\
\hline OZONENA & $\begin{array}{c}0.044046 \\
(2.07)\end{array}$ & $\begin{array}{l}0.02906 \\
(1.52)\end{array}$ & $\begin{array}{c}0.027091 \\
(1.50)\end{array}$ \\
\hline HGWYDENS & $\begin{array}{c}0.005914 \\
(2.35)\end{array}$ & $\begin{array}{c}0.003697 \\
(1.63)\end{array}$ & $\begin{array}{c}0.002898 \\
(1.36)\end{array}$ \\
\hline PCVIOLENT & $\begin{array}{c}0.004015 \\
(1.96)\end{array}$ & $\begin{array}{c}0.004668 \\
(2.54)\end{array}$ & $\begin{array}{c}0.005439 \\
(3.12)\end{array}$ \\
\hline \multicolumn{4}{|c|}{ Size and Metropolitan Characteristics } \\
\hline POPDENSITY & $\begin{array}{c}-0.01393 \\
(-2.98)\end{array}$ & $\begin{array}{c}-0.00857 \\
(-2.05)\end{array}$ & $\begin{array}{c}-0.00598 \\
(-1.51)\end{array}$ \\
\hline CNTRLCITY & $\begin{array}{c}0.049018 \\
(1.97)\end{array}$ & $\begin{array}{c}0.016405 \\
(0.73)\end{array}$ & $\begin{array}{c}0.013037 \\
(0.61)\end{array}$ \\
\hline SUBURBAN & $\begin{array}{l}0.08031 \\
(2.06)\end{array}$ & $\begin{array}{c}0.054723 \\
(1.58)\end{array}$ & $\begin{array}{c}0.035416 \\
(1.07)\end{array}$ \\
\hline
\end{tabular}


TABLE 3 (Continued)

Regression Findings: Wage Opportunity Locus

Dependent Variable $=$ Log of Total Compensation by Rank (t-statistics in parentheses)

\begin{tabular}{lccc}
\hline \hline & \multicolumn{3}{c}{ Faculty Rank } \\
& Full & Associate & Assistant \\
\hline & \multicolumn{2}{c}{ Fiscal Measures } \\
PCEDUCATN & $3.9 \mathrm{E}-05$ & $2.22 \mathrm{E}-05$ & $2.04 \mathrm{E}-05$ \\
& $(1.71)$ & $(1.08)$ & $(1.06)$ \\
PCPOLICE & -0.00046 & -0.00027 & -0.00023 \\
& $(-2.14)$ & $(-1.41)$ & $(-1.28)$ \\
PCWELFARE & 0.000213 & 0.000136 & $9.47 \mathrm{E}-05$ \\
& $(2.79)$ & $(1.99)$ & $(1.48)$ \\
EFFPROPTX & 0.011984 & 0.018573 & 0.014058 \\
& $(0.63)$ & $(1.09)$ & $(0.88)$ \\
INCOMETX & -0.00094 & 0.003108 & 0.001083 \\
& $(-0.28)$ & $(1.09)$ & $(0.39)$ \\
& Disequilibrium Measures & \\
MIDWEST & -0.02532 & -0.03245 & -0.01751 \\
& $(-0.89)$ & $(-1.26)$ & $(-0.72)$ \\
SOUTH & -0.01975 & -0.04617 & -0.04149 \\
& $(-0.68)$ & $(-1.76)$ & $(-1.67)$ \\
WEST & -0.08698 & -0.09102 & -0.04909 \\
& $(-2.18)$ & $(-2.52)$ & $(-1.44)$ \\
MIGRRATE & 0.000175 & 0.00028 & 0.000212 \\
& $(1.16)$ & $(2.05)$ & $(1.65)$ \\
& 67.12 & 55.98 & $49.73 *$ \\
$\mathrm{R}^{2}{ }_{\text {adjusted }}$ & 15.21 & 9.85 & 7.88 \\
\hline F-statistic & & & \\
\hline
\end{tabular}

*Joint F-test significant at the $95 \%$ level of confidence.

a negative but insignificant influence on all three faculty ranks, ${ }^{10}$ and both measures of university resources positively affect total compensation, although only LIBVOLUMES is significant.

Among the amenities considered in the AMENITY classification, only SUNSHINE is considered an amenity, and it is significant at least at the 90 percent level of confidence for all ranks of faculty. Both OZONENA and HGWYDENS have positive and significant effects on the compensation of full professors. Thus, the disamenities associated with highway density appear to dominate the accessibility effect. This is perhaps not surprising given that we have no control for proximity of faculty to the university. Violent crime (PCVIOLENT) is seen as a statistically significant disamenity for all three faculty ranks. ${ }^{11}$ 
Turning to variables in the SIZE category, full professors require significantly higher compensation to live in metropolitan areas, but prefer more densely populated areas once metropolitan status and other amenity measures are controlled. ${ }^{12}$ In addition, associate professors also prefer universities located in more densely populated counties. In the FISCAL category, the tax rates are generally positive, but they are not significant determinants of faculty compensation. However, the form of spending on local services does have a significant impact on compensation. For example, PCEDUCATN and PCWELFARE both have positive coefficients, with the latter statistically significant for full and associate professors. This implies that these faculty treat welfare expenditures as undesirable redistribution. In contrast, all three groups of faculty treat expenditures on police (PCPOLICE) as a good, with full professors significantly sacrificing total compensation in exchange for higher per capita expenditures on police.

Finally, when compared to the Northeast, all other regions are preferred. The coefficient on SOUTH is significant at the 90 percent level of confidence for associate and assistant professors, whereas the coefficient on WEST is significant at the full and associate ranks. Furthermore, all faculty require higher total compensation levels when the county in which they work has a high migration rate. The coefficient on MIGRRATE is significant at the 95 percent confidence level for associate professors, and at the 90 percent level for those at the rank of assistant professor.

\section{Implicit Price Estimates}

Implicit prices $\left(\tau_{\mathrm{ij}}\right)$ are derived as the partial differential of the antilog of the wage-opportunity locus with respect to various locational attributes. These prices are reported by academic rank, in Table 4 . Given that wage cuts imply that a location attribute is a good, we define $\tau_{\mathrm{ij}}=-\partial \mathrm{W}_{\mathrm{j}} / \partial \mathrm{X}_{\mathrm{i}}$ for rank $\mathrm{j}$ and attribute $\mathrm{i}$. By contrast, since institutional measures are proxies for human or physical capital which affect productivity, as well as other university features which determine faculty compensation, we express the partial differential as the wage increases which they generate. In general, the findings are consistent with theoretical expectations. Factors which are expected to be goods (e.g., SUNSHINE) have positive implicit prices, whereas variables such as OZONENA, and PCVIOLENT have negative prices. For most of the institutional measures and the various locational attributes, the implicit prices rise in absolute value with the rank. In addition, when compared to average compensation levels, it was typically the case that the percentage impact on total compensation of an absolute change in the attribute also rose with rank. Hence, both the absolute and relative importance of institutional and locational attributes increased with academic rank. ${ }^{13}$ 
TABLE 4

Implicit Price Estimates by Rank

\begin{tabular}{|c|c|c|c|}
\hline & $\begin{array}{c}\text { Full } \\
\text { Professor }\end{array}$ & $\begin{array}{l}\text { Associate } \\
\text { Professor }\end{array}$ & $\begin{array}{l}\text { Assistant } \\
\text { Professor }\end{array}$ \\
\hline & $\begin{array}{c}\text { Mean Predicted } \\
\text { Compensation } \\
\$ 70,675.06 \\
\end{array}$ & $\begin{array}{c}\text { Mean Predicted } \\
\text { Compensation } \\
\$ 52,704.30 \\
\end{array}$ & $\begin{array}{c}\text { Mean Predicted } \\
\text { Compensation } \\
\$ 44,198.99 \\
\end{array}$ \\
\hline \multicolumn{4}{|l|}{ Institutional Measures } \\
\hline PRIVATENONRELIG & $3625.32^{\mathrm{a}}$ & 1651.86 & 261.55 \\
\hline PRIVATERELIG & $5555.27^{\mathrm{a}}$ & $2886.52^{a}$ & 1575.49 \\
\hline PCTSENIOR & $292.25^{\mathrm{a}}$ & $180.57^{\mathrm{a}}$ & $203.55^{\mathrm{a}}$ \\
\hline PCTMALE & $527.82^{\mathrm{a}}$ & $203.97^{\mathrm{a}}$ & $124.22^{\mathrm{a}}$ \\
\hline UNION & -913.63 & -4.38 & -246.04 \\
\hline \multicolumn{4}{|l|}{ LIBVOLUME } \\
\hline (per 1000 volumes) & $1.79^{\mathrm{a}}$ & $0.51^{\mathrm{a}}$ & $0.44^{\mathrm{a}}$ \\
\hline R\&DPERFAC & 5.41 & 2.87 & 0.86 \\
\hline \multicolumn{4}{|l|}{ Amenity Measures } \\
\hline SUNSHINE & $189.26^{\mathrm{b}}$ & $177.23^{\mathrm{a}}$ & $110.06^{\mathrm{a}}$ \\
\hline HUMIDITY & -19.93 & -9.93 & -5.41 \\
\hline OZONENA & $-3112.97^{\mathrm{a}}$ & -1531.60 & -1197.38 \\
\hline HGWYDENS & $-418.00^{\mathrm{a}}$ & -194.85 & -128.10 \\
\hline PCVIOLENT & $-283.77^{a}$ & $-246.05^{a}$ & $-240.39^{a}$ \\
\hline \multicolumn{4}{|c|}{ Size and Metropolitan Measures } \\
\hline POPDENSITY & $984.30^{\mathrm{a}}$ & $451.39^{\mathrm{a}}$ & 264.47 \\
\hline CNTRLCITY & $-3464.38^{\mathrm{a}}$ & -864.63 & -576.23 \\
\hline SUBURBAN & $-5675.92^{\mathrm{a}}$ & -2884.15 & -1565.35 \\
\hline \multicolumn{4}{|l|}{ Fiscal Measures } \\
\hline PCEDUCATN & $-2.76^{b}$ & -1.17 & -0.90 \\
\hline PCPOLICE & $32.41^{\mathrm{a}}$ & 14.25 & 10.21 \\
\hline PCWELFARE & $-15.07^{\mathrm{a}}$ & $-7.18^{a}$ & -4.19 \\
\hline EFFPROPTX & -846.98 & -978.88 & -621.35 \\
\hline INCOMETX & 66.23 & -163.81 & -47.87 \\
\hline \multirow{4}{*}{\multicolumn{4}{|c|}{$\begin{array}{l}\text { Location Dummy } \\
\text { Variables and } \\
\text { Disequilibrium } \\
\text { Controls }\end{array}$}} \\
\hline & & & \\
\hline & & & \\
\hline & & & \\
\hline MIDWEST & 1789.46 & 1709.99 & 773.89 \\
\hline SOUTH & 1395.69 & 2433.54 & $1833.70^{\mathrm{a}}$ \\
\hline WEST & 6147.10 & $4797.33^{\mathrm{a}}$ & 2169.59 \\
\hline MIGRRATE & -12.39 & $-14.77^{a}$ & $-9.38^{\mathrm{b}}$ \\
\hline
\end{tabular}

\footnotetext{
"Values for institutional measures represent wage increases resulting from the characteristics of the institution. For the other categories, prices are wage cuts that result from locational characteristics.

${ }^{a}$ Coefficient in wage opportunity locus is significant at 95 percent level of confidence in two-tailed test.

${ }^{b}$ Coefficient in wage opportunity locus is significant at 90 percent level of confidence in two-tailed test.
} 


\section{Quality of Life Estimates}

Since the implicit price reflects the monetized value of a locational attribute, a quality of life index can be derived separately for each category of locationspecific factors and for all factors combined. For example, the monetized value of the amenity adjustment for a particular rank $j$ is defined as QOLI AMENITY $=\Sigma_{\mathrm{i}} \tau_{\mathrm{ij}} * \mathrm{X}_{\mathrm{i}}$ (for all $\mathrm{i}$ attributes in the amenity category), and can be derived for each university by academic rank. Its value reflects the reduction in compensation that results in return for the bundle of amenities and disamenities available at that site. We note that this index is driven completely by site characteristics and is not dependent on attributes of the institution. We derive the total quality of life index as the sum of the individual indices for the AMENITY, SIZE, FISCAL, and DISEQUILIBRIUM ${ }^{14}$ categories. We also point out that the MEDVALUE control variable is not included in the quality of life index. This is because the implicit prices derived from wage differentials fully reflect willingness to pay. Further, by controlling for median housing value, we are theoretically evaluating the individual locating at the edge of the city, where land rents are assumed to be uniform.

In Table 5, we report the predicted compensation, exclusive of the quality of life factors, ${ }^{15}$ followed by the quality of life adjustment for the top 20 and bottom 20 universities in the sample. The complete ranking is available from the authors on request. Thus, for example, the New Mexico Institute of Mining and Technology, which ranked number one in quality of life for all academic ranks, has a predicted total compensation for full professors of $\$ 91,794$, assuming no quality of life adjustments. However, total compensation declines by $\$ 14,624$ as a result of favorable amenities; it drops by $\$ 2$ as a result of the size and metropolitan characteristics; it drops $\$ 5,759$ as a consequence of disequilibrium (and/or unmeasured locational attributes); and it increases by $\$ 663$ as a result of an unfavorable mix of public goods and taxes. Thus, the overall quality of life adjustment to compensation is a reduction of $\$ 19,722$. Given the similarity across faculty rank of the various attributes, it is not surprising that quality of life rankings are also quite similar. The pairwise correlation between the quality of life ranking of full and associate professors is $\mathbf{0 . 9 4}$; it is 0.90 for full and assistant professors; and it is 0.96 for associate and assistant professors. In addition there are several interesting generalizations that can be derived from these findings. First and foremost, a distinct regional pattern emerges. Those institutions which rank in the top twenty are generally located in the Mountain and Pacific regions, regardless of rank. This is due to the prominence of the amenity component in the quality of life measure. Furthermore, institutions ranking high on quality of life have a relatively favorable disequilibrium influence. It is usually the case that the fiscal component 
TABLE 5

Quality of Life Rankings and Components: Full Professors

Top 20 Institutions

\begin{tabular}{|c|c|c|c|c|c|c|c|}
\hline \multirow[t]{2}{*}{$\mathrm{Ra}$} & \multirow[t]{2}{*}{ Institution Name } & \multirow{2}{*}{$\begin{array}{c}\text { Predicted } \\
\text { Compensation } \\
\text { (based solely on } \\
\text { institutional } \\
\text { characteristics) }\end{array}$} & \multirow[b]{2}{*}{ QOLI } & \multirow[b]{2}{*}{$\begin{array}{l}\text { Amenity } \\
\text { component }\end{array}$} & \multicolumn{3}{|c|}{$\begin{array}{l}\text { Quality of Life Adjustments } \\
\text { (compensation reduction from } \\
\text { location characteristics) }\end{array}$} \\
\hline & & & & & $\begin{array}{c}\text { Size } \\
\text { component }\end{array}$ & $\begin{array}{c}\text { Fiscal } \\
\text { component }\end{array}$ & $\begin{array}{l}\text { Disequilibr } \\
t \quad \text { compone }\end{array}$ \\
\hline 1 & Jew Mexico Inst. Min.\&Tech. & 91794 & 19722 & 14624 & 2 & -663 & 5759 \\
\hline 2 & Univ. of Illinois-Urbana & 109953 & 18989 & 7520 & -3294 & 12409 & 2354 \\
\hline 3 & Northern Arizona University & 94735 & 18501 & 13099 & 4 & -453 & 5851 \\
\hline 4 & University of Wyoming & 95316 & 16924 & 9889 & 6 & 246 & 6783 \\
\hline 5 & University of Montana & 93095 & 16530 & 10194 & 30 & -378 & 6684 \\
\hline 6 & Utah State University & 97996 & 16360 & 10361 & 57 & -398 & 6340 \\
\hline 7 & University of Arizona & 100544 & 15746 & 14004 & -3396 & -90 & 5228 \\
\hline 8 & Washington State University & 97646 & 15721 & 9924 & 18 & -738 & 6517 \\
\hline 9 & Oregon State University & 96986 & 14938 & 8449 & 97 & -1005 & 7397 \\
\hline 10 & Montana State University & 96492 & 14824 & 10555 & 19 & -1350 & 5600 \\
\hline 11 & Golden Gate University & 93810 & 14552 & -2868 & 12523 & -147 & 5044 \\
\hline 12 & Univ. of Calif.-San Fran. & 92193 & 14552 & -2868 & 12523 & -147 & 5044 \\
\hline 13 & University of Nevada, Reno & 90434 & 14070 & 10655 & -3427 & 1965 & 4877 \\
\hline 14 & Columbia U.-Teachers Coll. & 90317 & 13903 & 205 & 20153 & -6512 & 57 \\
\hline 15 & Columbia University & 106373 & 13903 & 205 & 20153 & -6512 & 57 \\
\hline 16 & Fordham University & 92194 & 13903 & 205 & 20153 & -6512 & 57 \\
\hline 17 & New York University & 97703 & 13903 & 205 & 20153 & -6512 & 57 \\
\hline 18 & New Mexico St. Univ-Main & 102624 & 13868 & 13682 & -3432 & -336 & 3954 \\
\hline 19 & U. New Mexico-Albuquerque & 92984 & 13762 & 9757 & -3051 & 1600 & 5456 \\
\hline 20 & Kansas State University & 95787 & 12261 & 9949 & 109 & -521 & 2724 \\
\hline
\end{tabular}

Bottom 20 Institutions

\begin{tabular}{|c|c|c|c|c|c|c|c|}
\hline \multirow[t]{2}{*}{ Rank } & \multirow[t]{2}{*}{ Institution Name } & \multirow{2}{*}{$\begin{array}{c}\text { Predicted } \\
\text { Compensation } \\
\text { (based solely on } \\
\text { institutional } \\
\text { characteristics) } \\
\end{array}$} & \multirow[b]{2}{*}{ QOLI } & \multirow[b]{2}{*}{$\begin{array}{l}\text { Amenity } \\
\text { component }\end{array}$} & \multicolumn{3}{|c|}{$\begin{array}{l}\text { Quality of Life Adjustments } \\
\text { (compensation reduction from } \\
\text { location characteristics) }\end{array}$} \\
\hline & & & & & $\begin{array}{c}\text { Size } \\
\text { component }\end{array}$ & $\begin{array}{c}\text { Fiscal } \\
\text { component }\end{array}$ & $\begin{array}{c}\text { Disequilibriun } \\
\text { component }\end{array}$ \\
\hline 155 & Emory University & 99579 & -1561 & 1190 & -3720 & 91 & 878 \\
\hline 156 & University of Rhode Island & 94663 & -1592 & 5326 & -5371 & -1031 & -516 \\
\hline 157 & SUNY at Binghamton & 94861 & -1631 & 6895 & -3170 & -5825 & 469 \\
\hline 158 & Lehigh University & 102328 & -1657 & 4455 & -2829 & -3031 & -252 \\
\hline 159 & Rensselaer Poly. Institute & 103136 & -1894 & 6568 & -3233 & -5539 & 310 \\
\hline 160 & Drew University & 90960 & -1916 & 4686 & -4776 & -1877 & 51 \\
\hline 161 & Syracuse University & 101751 & -1984 & 5798 & -2877 & -5412 & 507 \\
\hline 162 & University of Rochester & 101801 & -2021 & 5448 & -2412 & -5568 & 511 \\
\hline 163 & Carnegie-Mellon University & 100827 & -2205 & -269 & -1596 & -1103 & 763 \\
\hline 164 & Univ. of Pittsburgh-Main & 95826 & -2205 & -269 & -1596 & -1103 & 763 \\
\hline 165 & SUNY at Stony Brook & 96675 & -2453 & 3122 & -4199 & -1529 & 153 \\
\hline 166 & University of Connecticut & 95578 & -2464 & 5048 & -5378 & -1984 & -150 \\
\hline 167 & SUNY at Albany & 98068 & -2622 & 6716 & -5468 & -3573 & -297 \\
\hline 168 & Drexel University & 97803 & -2646 & -13117 & 8677 & 1218 & 576 \\
\hline 169 & Temple University & 92982 & -2646 & -13117 & 8677 & 1218 & 576 \\
\hline 170 & University of Pennsylvania & 105063 & -2646 & -13117 & 8677 & 1218 & 576 \\
\hline 171 & SUNY at Buffalo & 97273 & -3236 & 4834 & -2552 & -6361 & 843 \\
\hline 172 & Princeton Theol. Seminary & 98023 & -3352 & 1938 & -2045 & -3060 & -185 \\
\hline 173 & Princeton University & 103791 & -3352 & 1938 & -2045 & -3060 & -185 \\
\hline 174 & Georgia Institute of Tech. & 103069 & -3916 & -2984 & -2315 & 118 & 1265 \\
\hline 175 & Georgia State University & 91651 & -3916 & -2984 & -2315 & 118 & 1265 \\
\hline
\end{tabular}


TABLE 5 (Continued)

Quality of Life Rankings and Components: Associate Professors

Top 20 insintions

\begin{tabular}{lcc} 
Rank Institution Name & $\begin{array}{c}\text { Predicted } \\
\text { Compensation } \\
\text { (based solely on } \\
\text { institutional QOLI Amenity } \\
\text { characteristics) }\end{array}$ & $\begin{array}{c}\text { Quality of Life Adjustments } \\
\text { (compensation reduction from } \\
\text { location characteristics) }\end{array}$ \\
Size Fiscal Disequilibrium \\
\hline
\end{tabular}

1 New Mexico Inst. Min.\&Tech.

2 Northern Arizona University

3 University of Wyoming

4 University of Arizona

5 Univ. of Illinois-Urbana

6 Washington State University

7 University of Nevada, Reno

8 Utah State University

9 University of Montana

10 New Mexico St. Univ- Main

11 U. New Mexico-Albuquerque

12 Oklahoma State Univ.-Main

13 University of Mississippi

14 Oregon State University

15 Univ. of Northem Colorado

16 University of South Dakota

17 Montana State University

18 Texas Tech University

19 University of Idaho

20 Kansas State University

$\begin{array}{rrrrrr}60209 & 16031 & 13993 & 0 & -2297 & 4335 \\ 60430 & 15235 & 12721 & 2 & -1932 & 4444 \\ 61428 & 15025 & 9667 & 3 & -201 & 5556 \\ 63008 & 14680 & 13627 & -833 & -1816 & 3702 \\ 66790 & 14307 & 8149 & -786 & 4561 & 2383 \\ 61640 & 14057 & 9777 & 8 & -966 & 5238 \\ 59591 & 13299 & 10412 & -847 & 450 & 3284 \\ 61844 & 13010 & 10084 & 26 & -2127 & 5027 \\ 61629 & 12705 & 9976 & 13 & -2721 & 5437 \\ 64812 & 12360 & 13196 & -850 & -2169 & 2183 \\ 59028 & 11913 & 9925 & -675 & -1311 & 3974 \\ 61985 & 11854 & 10817 & 43 & -1628 & 2622 \\ 59990 & 11661 & 10057 & 22 & -1611 & 3193 \\ 61947 & 11491 & 8680 & 44 & -3520 & 6287 \\ 59417 & 11491 & 9935 & -848 & -2119 & 4523 \\ 58940 & 11426 & 9998 & 14 & -1913 & 3327 \\ 60375 & 11113 & 10283 & 9 & -3325 & 4146 \\ 60683 & 11093 & 10357 & -752 & -1237 & 2725 \\ 61606 & 11051 & 9976 & 7 & -4225 & 5293 \\ 60897 & 11009 & 10170 & 50 & -2036 & 2825\end{array}$

Bottom 20 Institutions

\begin{tabular}{|c|c|c|c|c|c|c|c|}
\hline \multirow[t]{2}{*}{ Rank } & \multirow[t]{2}{*}{ Institution Name } & \multirow{2}{*}{$\begin{array}{c}\text { Predicted } \\
\text { Compensation } \\
\text { (based solely on } \\
\text { institutional } \\
\text { characteristies) }\end{array}$} & \multirow[b]{2}{*}{ QOLI } & \multicolumn{4}{|c|}{$\begin{array}{l}\text { Quality of Life Adjustments } \\
\text { (compensation reduction from } \\
\text { location characteristics) }\end{array}$} \\
\hline & & & & $\begin{array}{l}\text { Amenity } \\
\text { component }\end{array}$ & $\begin{array}{c}\text { Size } \\
\text { component }\end{array}$ & $\begin{array}{c}\text { Fiscal } \\
\text { component }\end{array}$ & $\begin{array}{c}\text { Disequilibrium } \\
\text { component }\end{array}$ \\
\hline 155 & Univ. of Pittsburgh-Main & 60684 & 2910 & 3728 & -8 & -1719 & 909 \\
\hline 156 & Emory University & 62082 & 2811 & 4697 & -1987 & -1716 & 1817 \\
\hline 157 & Drexel University & 61964 & 2430 & -2226 & 4703 & -733 & 686 \\
\hline 158 & Temple University & 61035 & 2430 & -2226 & 4703 & -733 & 686 \\
\hline 159 & University of Pennsylvania & 65372 & 2430 & -2226 & 4703 & -733 & 686 \\
\hline 160 & Adelphi University & 58357 & 2382 & 5101 & -788 & -2109 & 178 \\
\hline 161 & Hofstra University & 59107 & 2382 & 5101 & -788 & -2109 & 178 \\
\hline 162 & University of Connecticut & 61847 & 2346 & 7149 & -2747 & -1877 & -179 \\
\hline 163 & Drew University & 60792 & 2065 & 7240 & -2471 & -2765 & 61 \\
\hline 164 & SUNY at Binghamton & 61211 & 1992 & 7514 & -729 & -5353 & 560 \\
\hline 165 & University of Rhode Island & 60970 & 1605 & 7532 & -2744 & -2568 & -615 \\
\hline 166 & Rensselaer Polytechnic In & 65566 & 1595 & 7199 & -758 & -5215 & 369 \\
\hline 167 & Syracuse University & 61918 & 1534 & 6713 & -595 & -5189 & 605 \\
\hline 168 & University of Rochester & 63210 & 1532 & 6573 & -382 & -5268 & 609 \\
\hline 169 & Princeton University & 62168 & 1203 & 4986 & -214 & -3349 & -220 \\
\hline 170 & Princeton Theol. Seminary & 65063 & 1039 & 4986 & -214 & -3513 & -220 \\
\hline 171 & Georgia Institute of Tech. & 64671 & 1016 & 778 & -337 & -1703 & 2278 \\
\hline 172 & Georgia State University & 58388 & 1016 & 778 & -337 & -1703 & 2278 \\
\hline 173 & SUNY at Stony Brook & 61636 & 954 & 6375 & -2206 & -3397 & 182 \\
\hline 174 & SUNY at Buffalo & 62430 & 846 & 5945 & -446 & -5658 & 1005 \\
\hline 175 & SUNY at Albany & 61733 & -161 & 7283 & -2788 & -4302 & -354 \\
\hline
\end{tabular}


TABLE 5 (Continued)

Quality of Life Rankings and Components: Assistant Professors

Top 20 Institutions

\begin{tabular}{|c|c|c|c|c|c|c|c|}
\hline \multirow[t]{2}{*}{ Rank } & \multirow[t]{2}{*}{ Institution Name } & \multirow{2}{*}{$\begin{array}{c}\text { Predicted } \\
\text { Compensation } \\
\text { (based solely on } \\
\text { institutional } \\
\text { characteristics) }\end{array}$} & \multirow[b]{2}{*}{ QOLI } & \multirow[b]{2}{*}{$\begin{array}{c}\text { Amenity } \\
\text { component }\end{array}$} & \multicolumn{3}{|c|}{$\begin{array}{l}\text { Quality of Life Adjustments } \\
\text { (compensation reduction from } \\
\text { location characteristics) }\end{array}$} \\
\hline & & & & & $\begin{array}{c}\text { Size } \\
\text { component }\end{array}$ & $\begin{array}{c}\text { Fiscal } \\
\text { component }\end{array}$ & $\begin{array}{l}\text { Disequilib } \\
t \quad \text { compon }\end{array}$ \\
\hline 1 & New Mexico Inst. Min.\&Tech. & 48044 & 9478 & 8696 & 0 & -1094 & 187 \\
\hline 2 & Northern Arizona University & 47295 & 8474 & 7393 & 1 & -865 & 194 \\
\hline 3 & University of Wyoming & 50468 & 8323 & 5822 & 1 & -151 & 2651 \\
\hline 4 & University of Arizona & 51042 & 8068 & 7860 & -557 & -709 & 147 \\
\hline 5 & Univ. of Illinois-Urbana & 55094 & 8024 & 4576 & -530 & 2777 & 20 \\
\hline 6 & Washington State University & 49820 & 7762 & 5951 & 4 & -642 & 244 \\
\hline 7 & Oklahoma State Univ.-Main & 50863 & 7756 & 6501 & 25 & -723 & 193 \\
\hline 8 & University of Mississippi & 48770 & 7735 & 6176 & 13 & -770 & 231 \\
\hline 9 & Utah State University & 49638 & 7563 & 6216 & 15 & -983 & 231 \\
\hline 10 & University of Montana & 50851 & 7403 & 6068 & 8 & -1249 & 25 \\
\hline 11 & Mississippi State Univ. & 50808 & 7136 & 5618 & 21 & -673 & 217 \\
\hline 12 & New Mexico St. Univ- Main & 54803 & 6888 & 7924 & -567 & -978 & \\
\hline 13 & Virginia Poly.Inst.\&St.Univ. & 52732 & 6810 & 5837 & 54 & -829 & 1748 \\
\hline 14 & University of Nevada, Reno & 48808 & 6763 & 5745 & -566 & 376 & 120 \\
\hline 15 & Kansas State University & 49683 & 6717 & 6183 & 29 & -976 & $14 \varepsilon$ \\
\hline 16 & Texas Tech University & 50348 & 6697 & 5998 & -510 & -810 & 2019 \\
\hline 17 & Oregon State University & 49929 & 6691 & 5307 & 26 & -1758 & 3116 \\
\hline 18 & Aubum University-Main & 49724 & 6685 & 5254 & 35 & -327 & 1723 \\
\hline 19 & U. of Southern Mississippi & 46749 & 6611 & 5350 & 37 & -694 & \\
\hline 20 & Montana State University & 47739 & 6583 & 6366 & 5 & -1543 & \\
\hline
\end{tabular}

Bottom 20 Institutions

\begin{tabular}{|c|c|c|c|c|c|c|c|}
\hline \multirow[t]{2}{*}{ Rank } & \multirow[t]{2}{*}{ Institution Name } & \multirow{2}{*}{$\begin{array}{c}\text { Predicted } \\
\text { Compensation } \\
\text { (based solely on } \\
\text { institutional } \\
\text { characteristics) }\end{array}$} & \multirow[b]{2}{*}{ QOLI } & \multicolumn{4}{|c|}{$\begin{array}{l}\text { Quality of Life Adjustments } \\
\text { (compensation reduction from } \\
\text { location characteristics) }\end{array}$} \\
\hline & & & & $\begin{array}{l}\text { Amenity } \\
\text { component }\end{array}$ & $\begin{array}{c}\text { Size } \\
\text { component }\end{array}$ & $\begin{array}{c}\text { Fiscal } \\
\text { component }\end{array}$ & $\begin{array}{l}\text { Disequilibrium } \\
t \text { component }\end{array}$ \\
\hline 155 & Carnegie-Mellon University & 51614 & 1213 & 1710 & -74 & -1000 & 577 \\
\hline 156 & Univ. of Pittsburgh-Main & 49535 & 1213 & 1710 & -74 & -1000 & 577 \\
\hline 157 & University of Rhode Island & 48961 & 1126 & 4315 & -1483 & -1316 & -390 \\
\hline 158 & Rensselaer Poly. Institute & 52718 & 1095 & 4280 & -514 & -2905 & 234 \\
\hline 159 & University of Rochester & 50450 & 1013 & 3793 & -293 & -2873 & 386 \\
\hline 160 & Syracuse University & 50652 & 1004 & 3873 & -418 & -2835 & 384 \\
\hline 161 & Michigan State University & 51523 & 973 & 2006 & -446 & -1860 & 1273 \\
\hline 162 & Western Michigan University & 50048 & 859 & 1507 & -473 & -1182 & 1007 \\
\hline 163 & Wayne State University & 50693 & 841 & -611 & 342 & -645 & 1755 \\
\hline 164 & SUNY at Stony Brook & 50487 & 726 & 3470 & -1168 & -1692 & 116 \\
\hline 165 & Boston College & 50212 & 395 & -2621 & 2544 & 393 & 79 \\
\hline 166 & Northeastern University & 49445 & 395 & -2621 & 2544 & 393 & 79 \\
\hline 167 & SUNY at Buffalo & 51015 & 370 & 3146 & -331 & -3083 & 638 \\
\hline 168 & SUNY at Albany & 49119 & 275 & 4345 & -1509 & -2336 & -225 \\
\hline 169 & Drexel University & 50519 & 121 & -2768 & 2686 & -233 & 436 \\
\hline 170 & Temple University & 50421 & 121 & -2768 & 2686 & -233 & 436 \\
\hline 171 & University of Pennsylvania & 53645 & 121 & -2768 & 2686 & -233 & 436 \\
\hline 172 & Princeton Theol. Seminary & 48605 & -162 & 2114 & -195 & -1941 & -140 \\
\hline 173 & Princeton University & 51962 & -162 & 2114 & -195 & -1941 & -140 \\
\hline 174 & Georgia Institute of Tech. & 53668 & -1327 & -2038 & -267 & -757 & 1735 \\
\hline 175 & Georgia State University & 47980 & -1327 & -2038 & -267 & -757 & 1735 \\
\hline
\end{tabular}


is negative, although it is small relative to the amenity and disequilibrium components. One notable exception is the comparatively high quality of life reported for the University of Illinois at Urbana, which ranks in the top 5 for all faculty primarily due to its favorable fiscal mix. In addition, the size and metropolitan component of quality of life is a small factor in the overall quality of life assessment for top 20 institutions for all ranks except full professors. This results from the relatively large impact of population density for full professors, which is more than twice that of associate professors, and more than 3.5 times larger than that of assistant professors.

An examination of the bottom 20 schools reveals a similar regional consistency. Most of these institutions are found in the Northeast, especially the Middle Atlantic states. While the amenity component of the overall index is typically positive, the size and fiscal components are consistently negative and strong. Moreover, the disequilibrium component is usually small relative to the other components. Finally, it interesting to note that at least among the universities considered in this study, the value of QOLI is typically positive, indicating that faculty are accepting cuts in compensation to live in those areas. In fact, full professors require positive adjustments to total compensation for only 31 of 175 universities in the sample. Assistant professors require such adjustments for just four of the universities, and associate professors display a negative QOLI for only one institution.

\section{Discussion}

These findings reflect a growing realization of the importance of quality of life factors such as air quality, public safety, and a favorable mix of public goods to workers. Indeed, the quality of life adjustments range between 7 and 12.8 percent (on average) of total compensation for professors in the sample of universities considered in this study. Moreover, the amenity component of quality of life is a strong determinant of the ranking of institutions for all faculty. While faculty compensation is the focus of this empirical investigation, the findings also apply to other occupations as well. In a society where workers and jobs are increasingly mobile over space, investigations of wage and total compensation differentials cannot ignore the relevance of location-specific factors in determining compensation levels. Important areas of research remain. This study examines aggregate data and due to data limitations does not distinguish between male and female or white and nonwhite implicit valuations. By extending this analysis to consider a microdata set, valuable insights can be derived regarding the relative importance of quality of life factors to these different groups of faculty. In addition, the issue of disequilibrium in faculty labor markets can be more readily addressed. 


\section{ENDNOTES}

1. In true long-run equilibrium, one would expect that variations in salaries across disciplines would be arbitraged away by the mobility of graduate students across fields so that remaining wage differences reflect differences in training costs, etc. However, this is the subject of another paper.

2. Henderson (1982) shows that wage differentials measure implicit prices only where average housing values are controlled in the hedonic wage equation.

3. See Kahn and Ofek (1992) for a thorough development of the dynamic relationship between local wages and population.

4. Clark and Kahn (1989) show that when an amenity is noncontinuous, willingness to pay may not be revealed in the estimated implicit price. Given that our data covers a wide range of geographic areas as well as central city, suburban and rural areas, we are confident that the assumption of continuity is satisfied in this application.

5. Faculty receive compensation in the form of both salary and fringe benefits. As a result, it would be inappropriate to simply examine salary data, since two institutions with identical salary levels may have very different levels of fringe benefits. Hence, we estimate the wage-opportunity locus in terms of total annual compensation (i.e., the sum of the salary and fringes).

6. When two or more metropolitan areas were equal, or near equal distance from a nonmetropolitan county, the metropolitan area which approximated the latitudinal location of the county in question was chosen.

7. While countywide property tax revenues per capita for 1987 are available, these are revenues from residential and nonresidential sources. Since we are interested in the impact of residential property taxes, we view the more aggregated statewide effective residential property tax rate as preferable.

8. Unfortunately, we do not have data on the migration rates of faculty, and thus we cannot derive more precise estimates of willingness to pay for locationspecific attributes in the same way that Greenwood, Hunt, Rickman and Treyz (1990) and Herzog and Schlottmann (1992) do.

9. Roback (1982) shows theoretically that wages and land rents are simultaneously determined by an interaction between the firms' spatial isocost and households' iso-utility surface. To test for the possible correlation between the median housing value and the error term, we conduct the Hausman specification test (Hausman, 1978). We find that the assumption of exogeneity of median housing value is upheld empirically.

10. Hamermesh and Woodbury (1992) find little effect of unionization of the campus on fringes, but a large effect of the statewide teachers' unionization on 
the level of fringes. Although we did not have the latter measure, we found no effect for the overall statewide unionization rate of all workers.

11. In commenting on an earlier draft of this paper, Daniel Hamermesh suggested that equity considerations in salaries across ranks constrain the compensation of faculty, especially among the most productive faculty. He noted that an interaction term between the various amenities and school quality variables may be important. There is some limited support for that contention. When we interacted LIBVOLUME and R\&DPERFAC with the various amenity measures, the variables SUNSHINE and HUMIDITY interacted with R\&DPERFAC were statistically significant in the equation for full professors. However, the coefficients on those interaction terms were positive. This implies that compensation for humidity was higher, but that such individuals place a smaller implicit value on sunshine. Furthermore, no other interaction terms were significant at the 95 percent level of confidence, and the standard errors increased for most of the amenities. Given that we were interested in developing precise estimates of implicit prices to derive quality of life indices, we chose to omit the interaction terms. However, if this study were to be conducted on a wider range of colleges and universities, then this interaction could become more important.

12. Following Herzog and Schlottmann (1993), we considered various combinations of population levels and population density, both in linear and quadratic form. In no case were the population or POPDENSITY ${ }^{2}$ variables significantly different from zero.

13. So as to ascertain the effects of large changes in site-specific factors, we also derived the percentage change in total compensation resulting when the sitespecific characteristics in the AMENITY, FISCAL and SIZE categories changed from their minimum to their maximum values. In the AMENITY category, the most substantial impacts were for SUNSHINE (total compensation fell 11 percent-15 percent), HGWYDENS (compensation increased 11 percent-23 percent) and PCVIOLENT (compensation rose 10 percent-14 percent). Of the variables in the FISCAL classification, the expenditure levels displayed relatively strong impacts, with changes in PCEDUCATN from the minimum to the maximum value increasing compensation between 48 percent and 91 percent, PCPOLICE decreasing compensation between 63 percent and 127 percent and welfare increasing compensation between 22 percent and 51 percent. Note, however, that these increases in expenditure typically represent changes on the order of 10 standard deviations. Interestingly, by contrast, tax variables display effects of less than 5 percent, even when tax rates increase from zero to their maximum value. Finally, changes in POPDENSITY from its minimum to its maximum value reduced total compensation between 14 percent and 33 percent overall. 
14. While the DISEQUILIBRIUM category is included to account for regional disequilibrium, we believe it is an important component of quality of life for at least two reasons. First, it captures unmeasured amenities and disamenities. For example, the coefficients on regional dummy variables inevitably capture the influence of temperature extremes and seasonal temperature variance. Second, even if regional dummy variables capture only disequilibrium influences, we believe that these influences affect the quality of life in the region. For example, if the dummy variable for the WEST region is negative and significant, this implies that total compensation is lower (after having accounted for equilibrium influences) than the omitted category. Thus, this cut in total compensation, which would be expected to be eventually eliminated by the movement of firms and households, reflects the decrease that residents are currently willing to accept to locate in that region.

15. The predicted compensation represents the sum of the antilog of the constant term, plus the additions to compensation resulting from the institutional characteristics.

\section{REFERENCES}

Barbezat, Debra A. (1987) "Salary Differentials by Sex in the Academic Labor Market." The Journal of Human Resources 22 (1987): 423-428.

Bayless, Mark. "Measuring the Benefits of Air Quality Improvement: A Hedonic

Salary Approach." Journal of Environmental Economics and Management 9 (1982): 81-99.

Berger, Mark C., Glenn C. Blomquist, and W. Waldner. "A Revealed-Preference Ranking of Quality of Life for Metropolitan Areas." Social Science Quarterly 68 (1987): 761-788.

Blomquist, Glenn C., Mark C. Berger, and John P. Hoehn. "New Estimates of Quality of Life in Urban Areas." American Economic Review 78 (1988): 89107.

Clark, David E., and James R. Kahn. "The Social Benefits of Urban Cultural Amenities." Journal of Regional Science 28 (1988): 363-377. . "The Two-Stage Hedonic Wage Approach: A Methodology for the Valuation of Environmental Amenities." Journal of Environmental Economics and Management 16 (1989): 106-120.

Greenwood, Michael J., Gary L. Hunt, Dan S. Rickman, and George I. Treyz. "Migration, Regional Equilibrium, and the Estimation of Compensating Differentials." American Economic Review 81 (1991): 1382-1390. 
Gyourko, Joseph, and Joseph Tracy. "The Importance of Local Fiscal Conditions in Analyzing Local Labor Markets." Journal of Political Economy 97 (1989): 1208-1231.

Hausman, Jerry A. "Specification Tests in Econometrics." Econometrica 46 (1978): 1251-1272.

Henderson, J. Vernon. "Evaluating Consumer Amenities and Interregional Welfare Differences." Journal of Urban Economics 11 (1982): 32-59.

Hoehn, John P., Mark C. Berger, and Glenn C. Blomquist. "A Hedonic Model of Interregional Wages, Rents, and Amenity Values." Journal of Regional Science 27 (1987): 605-620.

Herzog, Henry W., and Alan M. Schlottmann. "Valuing Amenities and Disamenities of Urban Scale: Can Bigger Be Better?." Journal or Regional Science 33 (1993): 145-165.

Jones, Ethel B., and Rand W. Ressler. "The South-Nonsouth Faculty Salary Differential." Eastern Economic Journal 19 (1993): 33-42.

Kahn, Shulamit. "Occupational Safety and Worker Preferences: Is There A Marginal Worker?" Review of Economic Statistics 69 (1987): 262-268.

Kahn, James R., and Haim Ofek. "The Equilibrium Distribution of Population and Wages in a System of Cities." Review of Regional Studies 22 (1992): 201216.

Katz, David A. "Faculty Salaries, Promotions, and Productivity at a Large University." American Economic Review 63 (1973): 469-477.

Kenny, L. W., and R. E. Studley. "Economists' Salaries and Lifetime Productivity." Unpublished paper, 1993.

Ofek, Haim, James R. Kahn, and David E. Clark. "The Urbanization Deflator of the GNP, 1919-1984: Reply." Southern Economic Journal 57 (1991): 11791182.

Rosen, Sherwin. "Wage-Based Indexes of Urban Quality of Life." in P. Mieszkowski and M. Strashaim (eds.). Current Issues in Urban Economics. Baltimore: Johns Hopkins University: 1979.

Roback, Jennifer. "Wages, Rents, and the Quality of Life." Journal of Political Economy 90 (1982): 1257-1278.

"Wages, Rents and Amenities: Differences Among Workers and Regions." Economic Inquiry 126 (1988): 23-41.

Tiebout, Charles M. "A Pure Theory of Local Expenditures." Journal of Political Economy 64 (1956): 416-424.

Weirick, William. "Amenities, Factor Mobility and Market Prices." Land Economics 63 (1987): 272-283.

Whaples, Robert. "The Urbanization Deflator of the GNP, 1919-1984: Comment." Southern Economic Journal 57 (1991): 1174-1178. 
Woodbury, Stephen A., and Daniel S. Hamermesh. "Taxes, Fringe Benefits and Faculty." Review of Economics and Statistics 74 (1992): 287-296. 